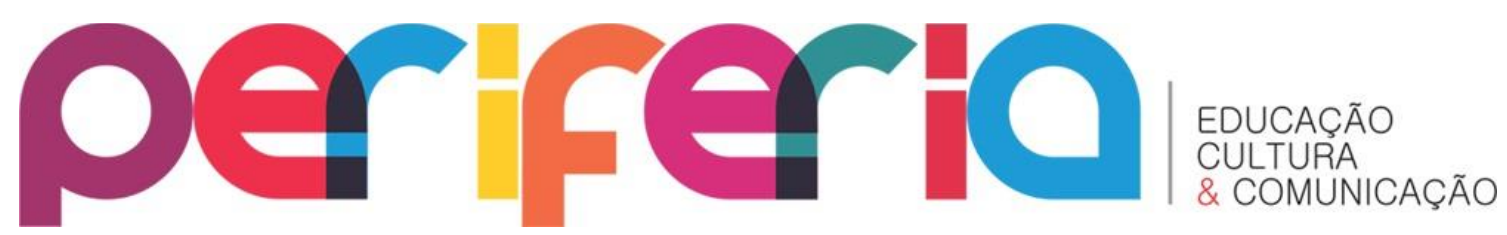

\title{
MEMES NA INTERNET: ENTRELAÇAMENTOS ENTRE A “ZOEIRA” DE ESTUDANTES E A APROPRIAÇÃO DO GÊNERO DISCURSIVO NA ESCOLA
}

\author{
Douglas de Oliveira Calixto ${ }^{1}$ \\ Universidade de São Paulo
}

\section{Resumo}

Este trabalho visa ao reconhecimento dos memes na internet como uma linguagem articuladora dos sentidos no interior da escola. Para além de mera brincadeira ou montagens que circulam nas redes sociais, demonstraremos como os memes representam uma nova forma de se relacionar com a comunicação e com a (ciber)cultura. A partir dos resultados da pesquisa de mestrado realizada com estudantes do ensino fundamental, pretende-se discutir (1) como o fenômeno da "zoeira" passou a ocupar o cotidiano de jovens e (2) como as dinâmicas das redes sociais estão inseridas em um contexto de transformação da sociedade contemporânea. Para tal empreendimento, apresentaremos a nossa elaboração teórica e metodológica que permitiu a aproximação com o conceito de "gênero discursivo meme" e, consequentemente, o nosso estudo sobre como essa linguagem opera nas relações entre Comunicação e Educação - a Educomunicação. A conclusão aponta para a alta relevância dos memes para a constituição das sociabilidades de alunos e alunas e apresenta direções para construir uma nova compreensão sobre o fenômeno.

Palavras-chave: memes na internet, Educomunicação, educação midiática, cibercultura, gênero discursivo

\footnotetext{
${ }^{1}$ Jornalista especializado em Comunicação e Educação. Mestrado em Ciências da Comunicação (ECA-USP). Integra o grupo de pesquisa MECOM (Mediações Educomunicativas), coordenado pelo prof. titular da ECA-USP Adilson Citelli. Idealizador do projeto Labeducom. E-mail: dcalixto@usp.br
} 


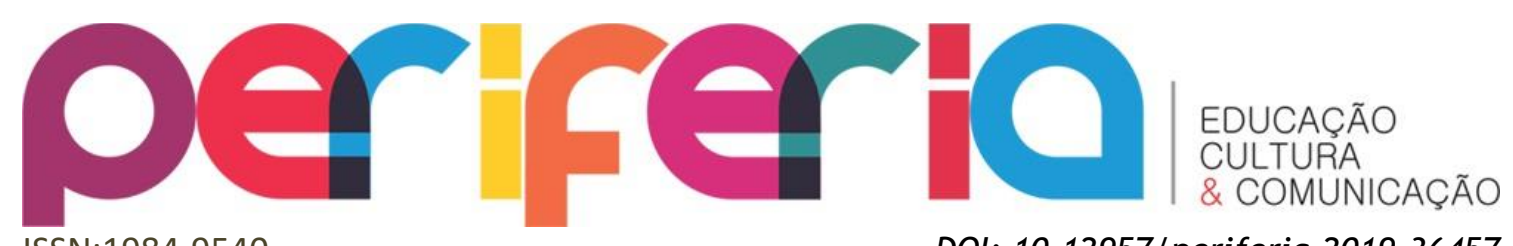

\title{
MEMES ON THE INTERNET: TRAINING BETWEEN THE "ZOEIRA" OF STUDENTS AND THE APPROPRIATION OF THE GENDER DISCURSIVE IN SCHOOL
}

\begin{abstract}
This work aims at the recognition of memes on the internet as a language that articulates the senses inside the school. Apart from mere jokes or mounts that circulate in social networks, we will demonstrate how memes represent a new way of relating to communication and (cyber) culture. From the results of the master's research carried out with elementary students, we intend to discuss (1) how the phenomenon of "zoeira" came to occupy the daily life of young people and (2) how the dynamics of social networks are inserted in a context of contemporary society. For such an undertaking, we will present our theoretical and methodological elaboration that allowed the approach to the concept of "discourse genre meme" and, consequently, our study on how this language operates in the relations between Communication and Education - Educommunication. The conclusion points to the high relevance of memes to the constitution of sociabilities of students and presents directions to build a new understanding about the phenomenon.
\end{abstract}

Keywords: memes on the internet, Educommunication, media education, cyberculture, discursive genre 


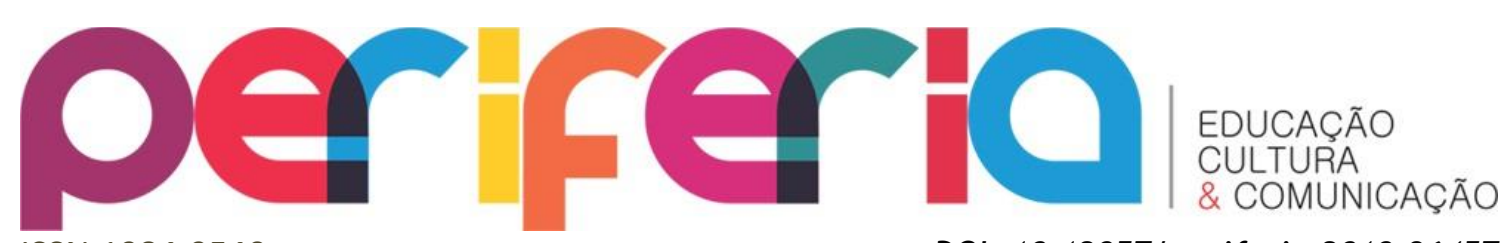

ISSN:1984-9540

DOI: 10.12957/periferia.2019.36457

\section{MEMES EN INTERNET: ENTRELECCIONES ENTRE LA "ZOEIRA" DE ESTUDIANTES Y LA APROPIACIÓN DEL GÉNERO DISCURSIVO EN LA}

ESCUELA

\section{Resumen}

Este trabajo busca el reconocimiento de los memes en Internet como un lenguaje articulador de los sentidos en el interior de la escuela. Además de mera broma o montajes que circulan en las redes sociales, demostraremos cómo los memes representan una nueva forma de relacionarse con la comunicación y con la (ciber) cultura. A partir de los resultados de investigación del maestro realizados con estudiantes de la escuela primaria, tenemos la intención de tratar (1) cómo el fenómeno del "alboroto" se trasladó a la juventud diario y (2) cómo la dinámica de las redes sociales están integrados en una contexto de transformación de la sociedad contemporánea. Para tal emprendimiento, presentaremos nuestra elaboración teórica y metodológica que permitió la aproximación con el concepto de "género discursivo meme" y, consecuentemente, nuestro estudio sobre cómo ese lenguaje opera en las relaciones entre Comunicación y Educación - la Educomunicación. La conclusión apunta a la alta relevancia de los memes para la constitución de las sociabilidades de alumnos y alumnas y presenta direcciones para construir una nueva comprensión sobre el fenómeno.

Palabras-clave: memes en la Internet, Educomunicación, educación mediática, cibercultura, género discursivo 


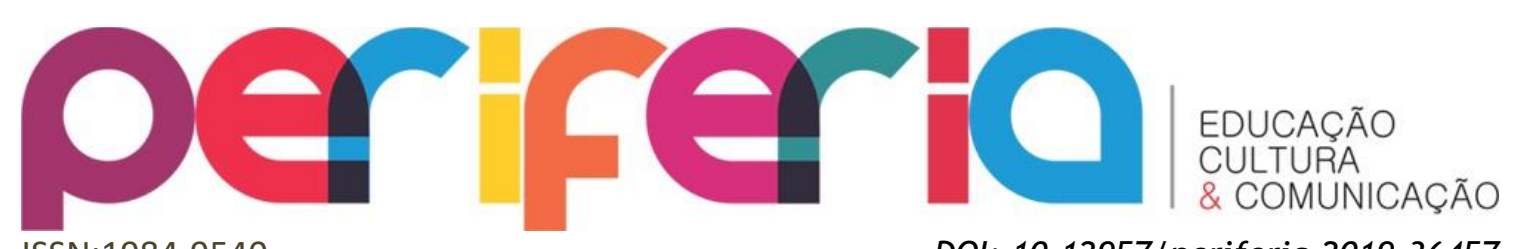

ISSN:1984-9540

DOI: $10.12957 /$ periferia.2019.36457

INTRODUÇÃO

A expressão "a internet não perdoa" passou a integrar o jargão jornalístico nos últimos anos. Em síntese, o conceito utilizado por repórteres e redatores faz referência a diversos acontecimentos da vida social que, ao despertar interesse dos usuários das redes sociais, se tornam objeto de crítica, paródia, deboches e piadas. São incontáveis exemplos de como artistas, personalidades, políticos, atletas profissionais entre outras categorias, ao cometer algum deslize ou gafe, se tornam - em poucos minutos - personagens de memes. Podemos, a título ilustrativo, citar alguns casos emblemáticos que circularam na imprensa no decorrer dos últimos anos: "Internet não perdoa e Temer é zoado em publicação com cachorro", "Neymar muda o visual e a internet não perdoa" e "Sandy se enrola ao cantar hit de Ivete Sangalo e internet não perdoa"2.

"Não perdoar", no caso, suscita uma das marcas da interação na web e que, na linguagem digital, se convém classificar como "zoeira sem limites". Zoar ${ }^{3}$ é uma forma de, a partir de alguma informação ou notícia que circula na internet, criar e compartilhar intervenções cômicas a respeito de um determinado tema. São, no geral, montagens e criações livres, que se manifestam em forma de meme.

Antes de avançarmos ao nosso estudo, é imperioso definir um conceito fundamental: marcado pelo discurso do entretenimento, dos prazeres rápidos e imediatos, os memes podem assumir uma dimensão de mero "oba-oba", sob a égide das superficialidades, que impedem uma compreensão mais aprofundada sobre o fenômeno. Num mundo marcado por injustiças sociais e agressões simbólicas nas redes, tal perspectiva compromete o entendimento das implicações socioculturais

\footnotetext{
${ }^{2}$ As três reportagens em questão apresentam a ação conjunta de usuários da internet para debochar, respectivamente, do presidente Michel Temer, do jogador de futebol Neymar e da cantora Sandy. Trata-se de publicações que circularam amplamente nas redes sociais e são encontradas facilmente com uma pesquisa simples no Google com o disparador "internet não perdoa".

${ }^{3} \mathrm{Na}$ classificação dicionarizada ${ }^{3}$, a palavra feminina zoeira exprime - entre outros tópicos que não servem para nossa classificação, como, por exemplo, quando remetem aos sons produzidos por insetos - (1) "aquilo que se faz com a intenção de ser engraçado, de provocar risos"; (2) "desordem; excesso de alvoroço; falta de ordem"; (3) "ação ou efeito de zoar; zoada"; (4) "Gritaria, som que não se consegue distinguir". "Zoar", nesse sentido, designa as interações que buscam provocar, ironizar, brincar ou parodiar situações do cotidiano por meio de memes e outros gêneros discursivos das redes sociais.
} 


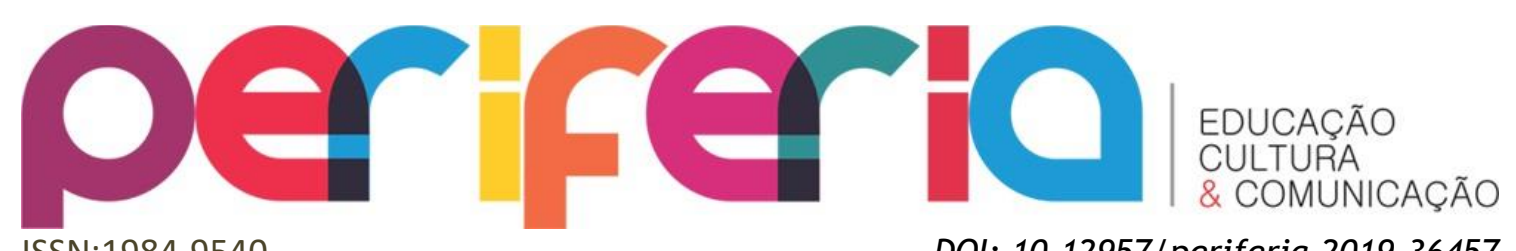

ISSN:1984-9540

das montagens e paródias no cotidiano da vida social. Nesse sentido, ao discutir esse assunto no universo da Educação, nosso esforço é de problematizar o objeto de pesquisa, tendo como enfoque a compreensão do funcionamento interno dessa linguagem, suas variações e, sobretudo, o conceito de gênero discursivo. Para além de determinismos tecnológicos, como explica Lemos (2015), o objetivo é compreender e construir pontes para um relacionamento mais consciente e responsável com as tecnologias. Nossa abordagem está comprometida com a promoção da cidadania a partir da compreensão dos códigos e significados desses novíssimos mecanismos comunicacionais. Isso não significa, em contrapartida, desprezar um dos elementos centrais da linguagem dos memes: a zoeira. Pelo contrário, buscamos conceituar o que são os deboches, as provocações e as montagens que buscam acionar o humor nas redes sociais.

Memes e zoeira se entrelaçam e são, mutuamente, elementos constitutivos do presente artigo. Trata-se de uma forma de participação entre usuários das redes sociais que, ao se valer da cultura de compartilhamento (LEMOS, 2015) e se apropriar de sistemas técnicos e produtos culturais (RECUERO, 2014), criam e ressignificam conteúdos - que podem ser imagens, vídeos, GIFs, notícias de portais da internet a fim de produzir sentidos, sobretudo de ironia, deboche e brincadeira, como nos casos de Michel Temer, Neymar e Sandy, citados acima.

A “zoeira sem limites” está em ampla circulação nas redes sociais e, neste artigo, nos desperta um interesse particular: apropriados em larga escala pelos jovens estudantes, essa manifestação cultural representa uma das principais expressões narrativas da internet, tendo desdobramento em como os jovens constroem a percepção de realidade. Conectar-se ao Facebook, Whatsapp, Instagram ou qualquer outro tipo de rede social implica quase que inevitavelmente na interação com algum tipo de montagem ou piada feita em forma de meme. E, no Brasil, os números são significativos: pelo menos 23 milhões de jovens interagem com as redes sociais (CGI, 2016).

Isso significa que os conteúdos, as mensagens e as paródias que circulam na web permeiam a cultura que jovens estão desenvolvendo no cotidiano. Iremos argumentar, neste artigo, que essa nova realidade comunicacional impõem desafios 


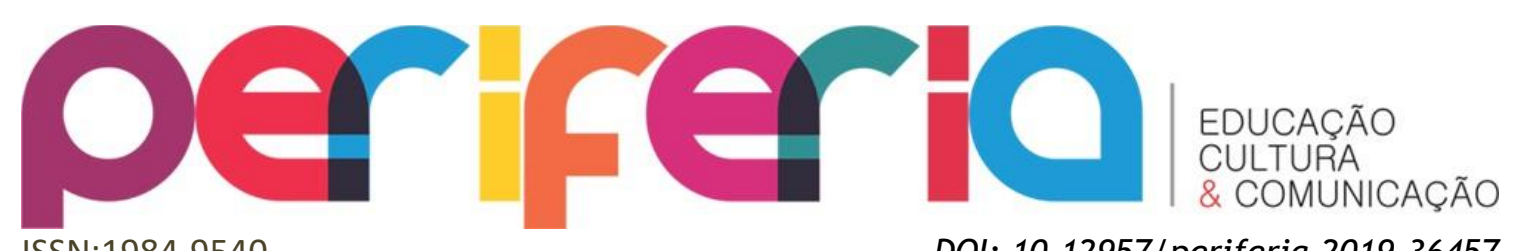

ISSN:1984-9540

para o universo da educação, afinal as redes digitais, na verdade, reorientam práticas e reconfiguram padrões de sociabilidade. Logo, há no universo escolar novas formas de ser, conhecer, comunicar e produzir. Essa transformação desloca a forma como o conhecimento é produzido e como os jovens estudantes se relacionam.

Nessa perspectiva, nosso referencial teórico atenta ao fato de ocorrer, hoje, no interior das escolas o cruzamento do universo infanto-juvenil com a cultura construída nas redes sociais por meio da circulação das mensagens, paródias e montagens dos memes. Trata-se do reconhecimento que, mesmo proibidos ou não inseridos no discurso escolar, as cadeias comunicativas acionadas pelos memes dinamizam o cotidiano de jovens estudantes. Ora, seja para provocar um amigo ou uma amiga no Whatsapp seja para referenciar uma situação corriqueira no Facebook, os memes passaram a ocupar lugar de destaque nas sociabilidades e na linguagem presente na sala de aula. A nossa pesquisa revela, em diversos níveis, que as montagens da internet são, em última instância, parte integrante cultura construída pelos jovens. Com essa delimitação, apresentaremos alguns dos resultados apreendidos na pesquisa de mestrado realizada com estudantes do ensino fundamental, na cidade de São Paulo, sobre como o fenômeno da "zoeira" dinamiza a interação entre os pares. Também iremos definir, a partir dos dados coletados, o conceito de "gênero discursivo meme" e como essa linguagem opera nas relações entre Comunicação e Educação - a Educomunicação.

O nosso objetivo é, nos limites de um artigo, apresentar aspectos relevantes da pesquisa que demonstram como os memes estão relacionados a uma nova realidade comunicacional com implicações diretas para a rotina dos discentes.

\section{A DEFINIÇÃO DE MEME: AS REFERÊNCIAS TEÓRICAS ENTRE COMUNICAÇÃO E EDUCAÇÃO}

A partir do trabalho de Richard Dawkins no livro o "O Gene Egoísta", há uma ideia amplamente difundida: os memes funcionam como replicadores da cultura (DAWKINS, 1976). Ou seja, são unidades e imitações que se reproduzem nas redes sociais em forma de contágio viral. Evidentemente as ideias de Dawkins estão 


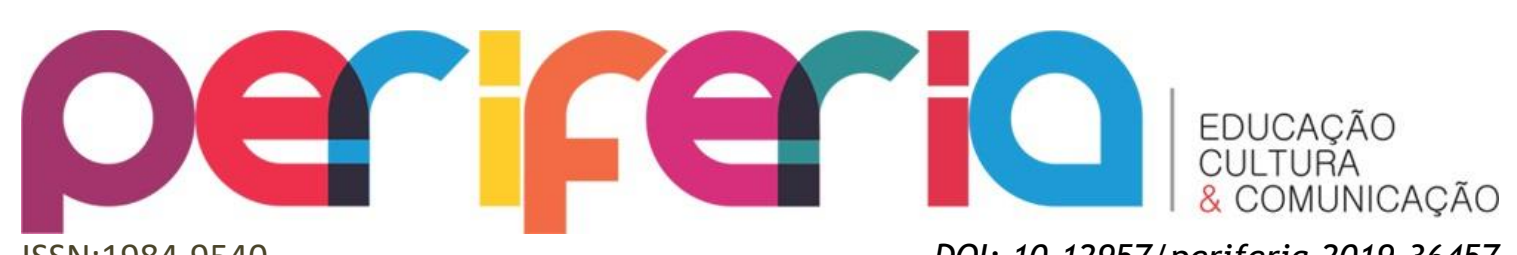

ISSN:1984-9540

DOI: 10.12957/periferia.2019.36457

inseridas num contexto de debate sobre a evolução das espécies e não temos pretensão de reduzir a obra do autor ou diminuir a importância dos estudos sobre a replicação da cultura. Buscamos apenas salientar alguns aspectos relevantes que nos ajudam na definição do fenômeno meme.

Entre os principais tópicos nos estudos de memética ${ }^{4}$, Dawkins (1976) elabora a expressão meme para, a partir do estudo da evolução, argumentar que as ideias e a própria cultura circulam na sociedade como a propagação dos genes humanos. $\mathrm{Da}$ redução da palavra mimeme (que significa imitação em grego), a intenção é ser semelhante à palavra gene para conceituar que, por meio de cópias e imitações, pequenas unidades da cultura passam de pessoa para pessoa, carregando em seu interior percepções gerais da sociedade. Se, de um lado, os genes são responsáveis pela formação de nossas características físicas, por outro lado os memes são responsáveis por manter vivos os aspectos culturais da convivência humana. Nessa perspectiva, meme é aquilo que é imitado a fim de se reproduzir e proliferar (BLACKMORE, 2008).

Shifman (2014) argumenta que o referencial teórico calcado exclusivamente nos pressupostos de "O Gene Egoísta" não é suficiente para explicar a circulação dos memes na sociedade contemporânea. Em nosso entendimento, a ideia de "replicador da cultura" ou a proposta de memes como "vírus" da mente (DAWKINS, 1976) não atendem a abrangência do que esses artefatos se tornaram atualmente. A comunicação prevê interação e trocas simbólicas dentro da trama cultural. Esta ideia não é tão óbvia quando pensamos que a comunicação é comumente confundida com a mídia, ou seja, com produtos midiáticos e seus respectivos instrumentos de emissão e recepção. $\mathrm{Na}$ abordagem que propomos, que pressupõe a comunicação dentro da cultura, numa relação ecossistêmica (CITELLI, 2004; MARTÍN-BARBERO, 1997; BACEGGA, 2011), o substancial é compreender como os sujeitos (especificamente em

\footnotetext{
${ }^{4}$ Em síntese, o conceito de memética faz referência a pesquisadores e pesquisadores que utilizam a obra de Dawkins para investigar atributos gerais da circulação dos memes na sociedade, como, por exemplo, as categorias de longevidade, fecundidade e fidelidade de cópia. De maneira geral, os estudos de memética apontam que as percepções culturais que circulam na sociedade são definidas pela seleção natural, ou seja, só sucedem aqueles que conseguem se adaptar às condições e evoluir. Trata-se de uma comparação ao funcionamento dos genes humanos que, em diversos níveis e diferentes perspectivas teóricas, busca estudar as razões para determinadas ideias e gostos se proliferarem de cabeça a cabeça, como vírus.
} 


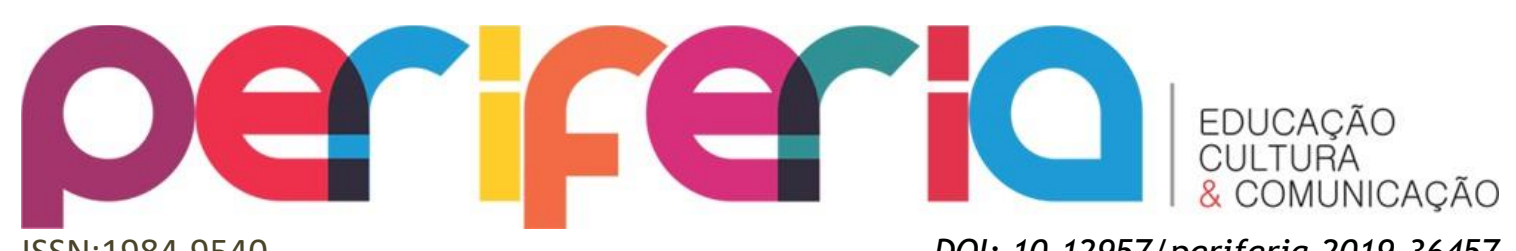

ISSN:1984-9540

DOI: $10.12957 /$ periferia.2019.36457

nosso estudo, estudantes do ensino fundamental) se relacionam com os processos comunicacionais contemporâneos e com a teia de significados que emergem a partir das linguagens digitais.

O objetivo de trazer uma alternativa teórica aos estudos de memética é demonstrar como os memes são, na verdade, um fenômeno comunicacional, que se organiza em funções de linguagem e cadeias comunicativas. Isso significa que, com as montagens e a "zoeira sem limites", os memes atendem necessidades comunicativas dos usuários da internet dentro da trama cultural contemporânea. Os gêneros discursivos permitem que os usuários da língua possam construir relações, funcionando de acordo com os contextos e as necessidades de operar a linguagem. Ou ainda:

Os diferentes enunciados orais ou escritos, produzidos pelos usuários da língua, constituem gêneros textuais. Exemplifica-se: telefonema, discurso, palestra, piada, bate-papo, romance, conto, crônica, artigo de opinião, reportagem, editorial, conto popular, lenda, apólogo e artigo de divulgação científica. Bakthin coloca que "a diversidade desses gêneros deve-se ao fato de eles variarem conforme as circunstâncias, a posição social e o relacionamento pessoal dos parceiros (KÖCHE \& MARINELLO, 2015, p.9)

Como artefatos culturais construídos historicamente pelo ser humano (MARCUSHI, 2009), os gêneros surgem em razão das necessidades comunicativas dos indivíduos dentro da vida social. Os memes, nesse sentido, materializam as necessidades comunicativas do contexto histórico-social ao qual pertencem: a sociedade contemporânea, altamente marcada pela comunicação descentralizada e a dinâmica dos mercados de consumo e das redes digitais. Foram as transformações econômicas e sociais e também as inovações tecnológicas que permitiram a atual produção material e imaterial da atualidade, que permitem a circulação de memes em diversas plataformas, como Facebook, Whatsapp e Intagram. Dantas (2002) explica que as redes e os sistemas de informação foram construídos em comunhão com o desenvolvimento do capital. Logo, o sucesso dos memes não é obra do acaso: temos no mundo contemporâneo uma nova forma de produzir e comunicar influenciada pelo tempo acelerado e dinâmico dos mercados. Os memes são uma das 


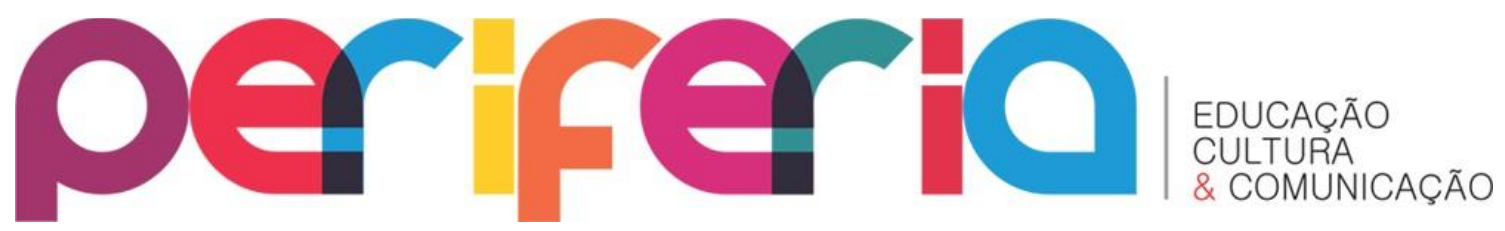

ISSN:1984-9540

DOI: $10.12957 /$ periferia.2019.36457

principais expressões narrativas desse movimento: com montagens simples, recortes feitos com uma estética amadora, os memes produzem sentidos rápidos e dinâmicos, prontos para serem esquecidos em poucos minutos. As montagens também não exigem alto padrão de qualidade ou geram preocupações pela repercussão estética: os memes são montagens feitas com textos e imagens, interdiscursivas, que referenciam situações do cotidiano, celebridades de televisão, rádio, web e assim por diante. Essa é a imbricação que nos permite a definição do gênero discursivo meme:

\begin{abstract}
Já se tornou trivial a ideia de que os gêneros textuais são fenômenos históricos, profundamente vinculados à vida cultural e social. Fruto de trabalho coletivo, os gêneros contribuem para ordenar e estabilizar as atividades comunicativas do dia-a-dia.São entidades sócio-discursivas e formas de ação social incontornáveis em qualquer situação comunicativa. No entanto, mesmo apresentando alto poder preditivo e interpretativo das ações humanas em qualquer contexto discursivo, os gêneros não são instrumentos estanques e enrijecedores da ação criativa. Caracterizam-se como eventos textuais altamente maleáveis. dinâmicos e plásticos. Surgem emparelhados a necessidades e atividades socioculturais, bem como na relação com inovações tecnológicas, o que é facilmente perceptível ao se considerar a quantidade de gêneros textuais hoje existentes em relação a sociedades anteriores à comunicação escrita. (MARCUSCHI, 2009).
\end{abstract}

Operar a linguagem pressupõe a escolha de gêneros para interação com os pares. Por exemplo, nas redes sociais, os jovens se negam, muitas vezes, a utilizar o mecanismo do textão ${ }^{5}$. Como as redes sociais operam sob o imperativo da pressa, da alta velocidade, há pouco espaço e paciência para enunciados longos e reflexivos. Essa é a razão dos jogos rápidos e dinâmicos dos memes, organizados em micronarrativas, acionarem os sentidos necessários para atender a demanda dos usuários da internet.

\footnotetext{
${ }^{5} \mathrm{~A}$ expressão textão remete aos enunciados produzidos nas redes sociais que ultrapassam um limite de caracteres "tolerados" pelos usuários da internet. Ou seja, quando um texto excede um padrão de rapidez e alta síntese, ele é classificado como "textão". Tanto é que algumas publicações das redes sociais, antes mesmo do título, são acompanhadas da expressão "Alerta de Textão" para que todos saibam que alguém está irrompendo com as tradicionais publicações e irá apresentar algo de maior extensão. Os textões, na linguagem digital, geralmente são associados às narrativas chatas ou que exigem um grau de atenção mais alto que a efemeridade dos memes
} 


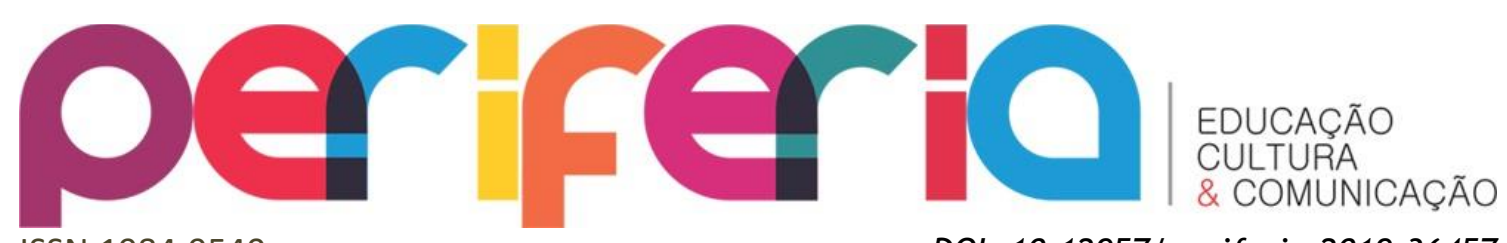

ISSN:1984-9540

Ao trazer essa perspectiva dos gêneros discursivos para o interior do universo da Educação e ao acionar o conceito de Educomunicação, consideramos a centralidade que a mídia ocupa atualmente nas dinâmicas formativas, nas relações entre estudantes e professores e, sem dúvida, na formação intelectual dos alunos. Com as possibilidades de comunicação organizadas em redes rizomáticas (SHIRKY, 2012), faz mais sentido pensar a entrada da mídia nos espaços educativos a partir do conceito de ecossistema comunicativo (MARTÍN-BARBERO, 1997). Este pressupõe que a mídia funciona como agência de socialização, sendo decisiva para a forma como nos relacionamos com o mundo. Assim, ao tratar de como os estudantes se relacionam com os memes, nossa preocupação teórica é investigar as tensões e as cadeias comunicativas do gênero meme e, consequentemente, como os bens simbólicos que circulam nas redes sociais têm desdobramentos nas sociabilidades de alunos e alunas. Ou ainda:

A comunicação transformou-se em dimensão estratégica para o entendimento da produção, circulação e recepção dos bens simbólicos, dos conjuntos representativos, dos impactos materiais afinal estamos falando, também, de uma indústria que faz computadores, vende celulares, televisores de alta definição etc. Tal conjunto de sistemas e processos está provocando profundas transformações sociais, de algum modo promovendo impactos diretamente na vida dos homens e mulheres do nosso tempo, quer velando, quer revelando ou desvelando informações e conhecimentos. À totalidade desses circuitos de retroalimentação envolvendo desde o plano da produção material, passando pelas estratégias de composição e circulação das mensagens, chegando aos jogos coenunciativos, podemos chamar de ecossistema comunicativo - conceito utilizado, em sentido próximo, por autores como Mario Kaplún, Jesús Martín-Barbero, Pierre Lévy, Adilson Citelli e Ismar Soares. (CITELLI, 2011, pg.62)

Nessa perspectiva, o foco de reconhecer os memes como um gênero discursivo está na construção de identidades e nas ressignificações dos conteúdos feitas pelos estudantes nas redes sociais. Foi nesse sentido que realizamos uma investigação de campo, que teve como objetivo central observar, descrever e analisar os sentidos atribuídos por estudantes do ensino fundamental aos memes. Em termos de redes sociais, outra possibilidade analítica é violência empregada na internet por meio de 


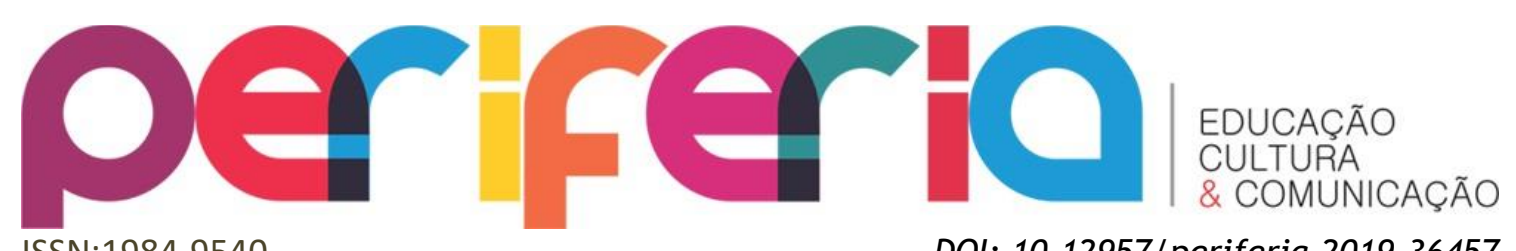

ISSN:1984-9540

memes. No presente artigo não exploraremos essa fronteira, porém, pensando no contexto das interações em rede, sobretudo pela alta frequência da utilização da internet, é possível afirmar que os jovens estão imersos em cultura altamente influenciada por bullying digital, vazamentos de fotos íntimas e boatos disseminados nas redes sociais (CALIXTO, 2017). A própria dimensão política, as reduções, apropriações e transgressões da norma culta para provocar o riso, são elementos constitutivos dos memes e merecem uma atenção analítica, como propõe Lulkin (2007). No entanto, mesmo que num exercício de síntese, é sobre o gênero discursivo que buscamos estruturar a nossa análise.

\section{A PESQUISA SOBRE MEMES: QUESTÕES METODOLÓGICAS}

$\mathrm{Na}$ investigação de campo, foram organizados dois grupos de referência, formados por nove discentes integrantes da Rádio JMS (projeto educomunicativo da EMEF Julio Marcondes Salgado) e nove discentes que não participam do referido projeto. Com o número reduzido de participantes, não foi possível apresentar generalizações a partir da interpretação dos dados coletados. Portanto, a amostragem é de representatividade social (não-estatística) (LOPES, 2005). Em termos metodológicos, adotamos o modelo proposto por Lopes (2005). Essa opção tem como objetivo desenvolver uma construção metodológica constante que, a partir do referencial teórico, orienta as estratégias conforme a construção do objeto. Como, em termos de coleta de dados, as pesquisas sobre memes ainda são recentes, carecendo de reflexões críticas no âmbito da Comunicação, com Lopes (2005), tivemos instrumentos de pesquisa que permitiram uma estratégia aberta e sempre pronta para adequações. A fim de construir dados significativos à análise qualitativa a partir da amostragem no qual trabalhamos, cruzamos três instrumentos para levantar os dados capazes de oferecer elementos analíticos ao nosso objeto de pesquisa, a saber:

(a) a observação direta, realizada na sala de informática da EMEF Julio Marcondes Salgado, com dois grupos de alunos. Esse método foi traduzido em fichas de observação dos quatro encontros e também com gravações feitas em vídeo da 


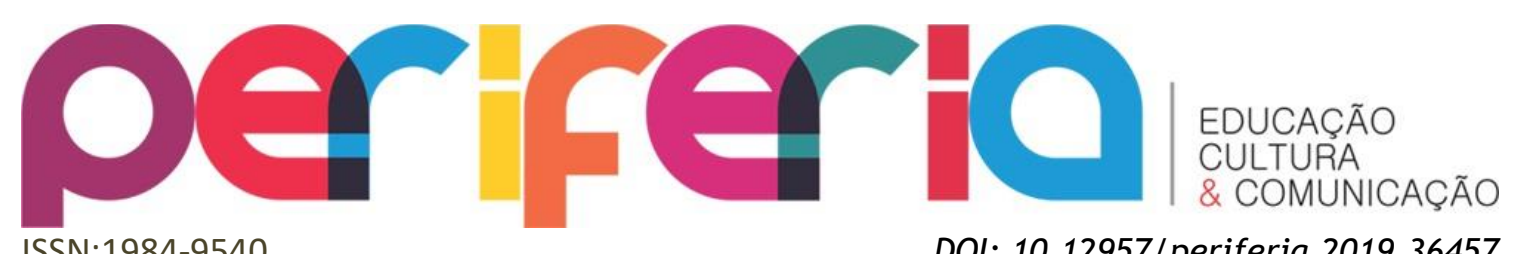

ISSN:1984-9540

DOI: 10.12957/periferia.2019.36457

interação dos estudantes com os memes. Além disso, também como parte da observação, realizamos entrevistas informais, uma vez que perguntas eram feitas enquanto os estudantes interagiram com os memes nos computadores da escola. Os depoimentos também foram registrados nas fichas de observação e nos vídeos;

(b) sistematização dos memes coletados pelos estudantes durante a realização da pesquisa na sala de informática;

(c) e, como forma de encerramento dos encontros feitos com os estudantes, realizamos uma Roda de Conversa com o objetivo de discutir, a partir da própria perspectiva dos jovens, as percepções e os significados que eles atribuem ao memes;

Foi na integração dos procedimentos ( $a$, b e c) que os dados para realizar sistematizações, comentários e interpretações foram obtidos. Consequentemente, na etapa posterior já com a sistematização dos dados realizada, foi feita a categorização de gêneros e subgêneros que constatamos nas dinâmicas relacionadas aos memes. No processo de investigação, decidimos não utilizarmos os métodos de Análise de Redes Sociais (RECUERO, 2014). A partir das preocupações relacionadas aos conceitos de gênero discursivo e ecossistema comunicativo, preferimos focalizar os depoimentos e a observação dos jovens interagindo com as redes sociais. Como constatamos nas entrevistas iniciais da pesquisa, estudantes do Ensino Fundamental II têm alta familiaridade com a linguagem da internet, o que garantiu densidade na interlocução com participantes da investigação. Assim, no processo de sistematização e análise dos dados coletados tivemos como objetivo, a partir da abordagem qualitativa, dar ordem às recorrências mais frequentes e os jogos de linguagem estipuladas entre os estudantes.

\section{ANÁLISE DO MATERIAL COLETADO: OS SENTIDOS ATRIBUÍDOS AOS MEMES}

A dinâmica metodológica, deliberadamente sintetizada pelo espaço deste artigo, nos permitiu chegar a três categorias de análise sobre o gênero discursivo meme: cotidiano, afetos e zoeira. Para criar as três categorias partimos da premissa que, a partir de referencial teórico articulado com os procedimentos metodológicos, recorrências, concentrações e similaridades podem ser entendidas 


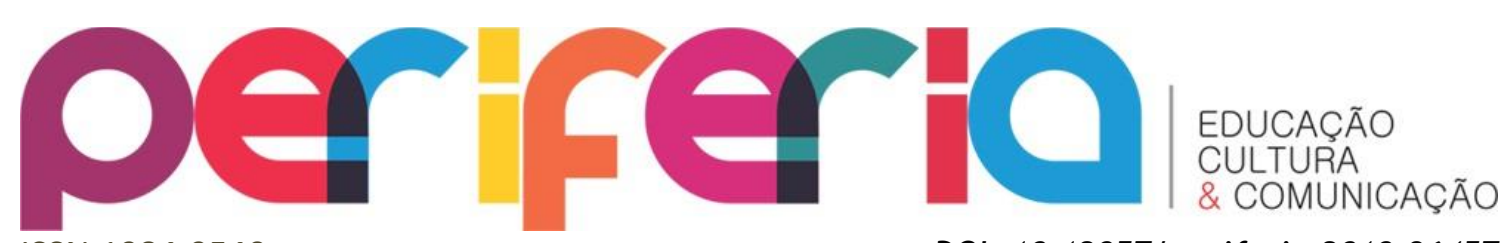

ISSN:1984-9540

DOI: $10.12957 /$ periferia.2019.36457

como um critério. Entre os dados coletados, não buscamos sistematizações numéricas - como, por exemplo, quantas vezes um meme foi mencionado -, mas sim os fatos de significação, ou seja, ocorrências capazes de nos dar elementos de análise sobre Educomunicação, cibercultura e o "gênero discursivo meme". Passamos a apresentar os resultados das categorias ${ }^{6}$ :

\subsection{Os memes do cotidiano}

Com o material obtido a partir da investigação, pudemos identificar, a partir do trabalho de sistematização dos dados, que os estudantes utilizam expressões típicas da linguagem dos memes para dialogar entre os pares sobre situações do cotidiano. Uma expressão muito utilizada chamou à atenção nos depoimentos colhidos junto aos estudantes: "esse meme é muito a minha vida". Citações semelhantes a esta também foram recorrentes, como, por exemplo, "isso já aconteceu comigo", "isso acontece o tempo todo na escola", "minha mãe, irmã, pai, irmão fazem isso". Os memes coletados que faziam referência a essas expressões remetiam às dinâmicas do dia-dia, da escola, dos amigos, da família e assim por diante. Como explica Shifman (2014), os memes podem ser vistos como uma espécie de folclore moderno, justamente por sintetizar acontecimentos e dinâmicas das cidades e do cotidiano. Muitos dos memes apontados pelos estudantes se interrelacionavam com essa perspectiva. Para evidenciar a categoria de "cotidiano", selecionamos um meme compartilhado por um estudante participante da pesquisa e o respectivo depoimento atribuído a esse meme.

\footnotetext{
${ }^{6} \mathrm{Na}$ dissertação "Memes na internet: entrelaçamentos entre educomunicação, cibercultura e a 'zoeira' de estudantes nas redes sociais", a metodologia de pesquisa é explicada em detalhes a partir da construção teórica feita sobre os memes e a inter-relação Comunicação e Educação. A fim de reservarmos um espaço para a apresentação dos resultados, tivemos que apresentar uma síntese do que foi feito. A íntegra da dissertação pode ser acessada no banco de dissertações e teses da USP. Disponível em:

< http://www.teses.usp.br/teses/disponiveis/27/27154/tde-01112017-102256/pt-br.php>
} 


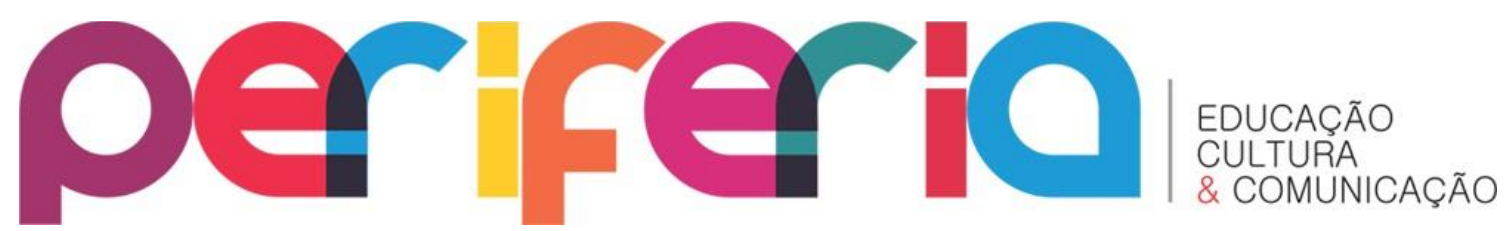

ISSN:1984-9540

DOI: $10.12957 /$ periferia.2019.36457

Imagem 1 - Meme selecionado por estudante do ensino fundamental durante pesquisa de campo

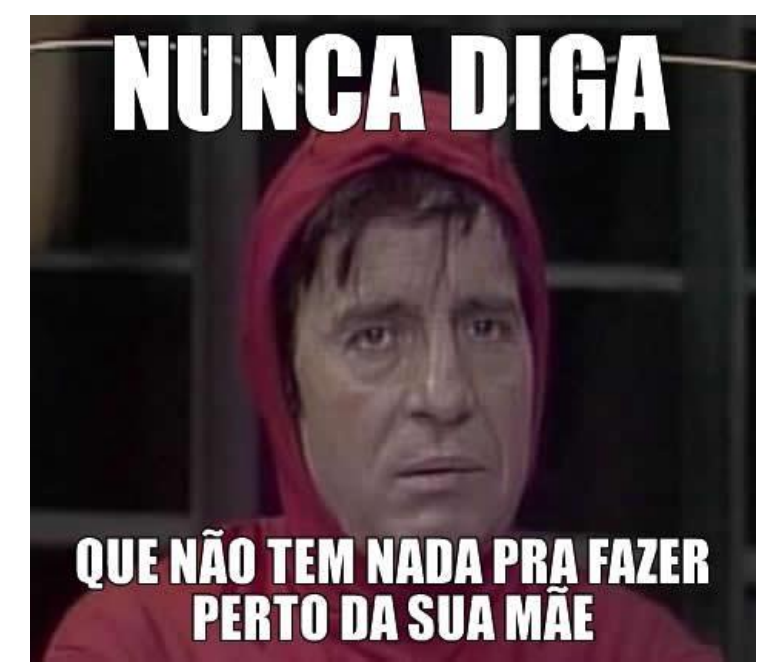

Fonte: Facebook (2016). Legenda: Meme retirado da página “Chapolin Sincero” por uma das participantes da pesquisa. Na montagem, o personagem Chapolin - que é muito popular na linguagem dos memes - ironiza as frequentes cobranças das mães para que tarefas sejam realizadas.

Esse meme é muito a minha vida. Minha mãe olha pra mim e já me manda trabalhar, depoimento registrado na investigação de campo da estudante ao nos mostrar a Imagem 1, meme do Chapolin.

Os memes e o consequente depoimento da estudante entrevistada evidenciam como as dinâmicas do dia-a-dia são expressas nas montagens. Ora, devemos considerar que a linguagem cumpre certas funções. Logo, assume-se que "uma série de mecanismos é acionada - de forma mais ou menos consciente - pelos usuários, com a finalidade de construir teses, elaborar ideias, assumir pontos de vista e rechaçar preconceitos" (CITELLI, 1994, p. 8). Nesse sentido, podemos definir que uma das funções dos memes é elaborar e narrar relações e peripécias do cotidiano.

Ou seja, é por meio das montagens e remodelagens que os memes constituem micronarrativas que operam as representações e as produções de sentido sobre o desenrolar das atividades cotidianas. Devemos pontuar, em contrapartida, que os 


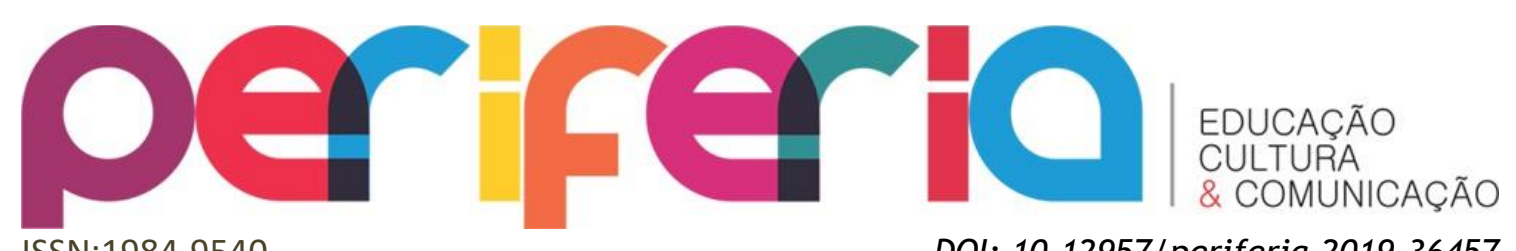

ISSN:1984-9540

DOI: $10.12957 /$ periferia.2019.36457

memes não servem apenas para transmitir pensamentos ou para se reproduzir através dos seus replicadores, como discutimos na obra de Dawkins. Pelo contrário: é na dialética entre pensamento e linguagem, como uma unidade híbrida, que a produção de sentido é acionada. Alguns outros depoimentos colhidos juntos aos estudantes participantes da pesquisa indicam essa dimensão:

Sempre tem um meme para falar dessas coisas que acontecem na escola. Intervalo, professor bravo, gente colando na prova. Depoimento 1.

É os memes da vida real. Tem uma página só sobre isso. Só de zoeira que acontece na vida. Quando você tá em casa, tá jogando video-game, quer falar com os amigos. Depoimento 2.

Os memes que eu mais gosto é quando serve para mandar para alguém da escola. Para alguém que precisa ver umas verdades. Depoimento 3.

\subsection{Memes dos afetos}

Constatamos que os memes cumpriam uma função de dinamizar as relações estabelecidas entre os estudantes entrevistados. Jogos de paquera, amizades e inimizades com colegas, tensões e paixões com a família e outras manifestações do gênero ocorreram nos depoimentos e nos sentidos atribuídos aos memes. Concluímos que os memes carregam não apenas junções de textos, vídeos e imagens, mas sim sistemas imagéticos, montagens que unem movimentos, sons, cores e assim por diante. Memes fazem referência a programas de TV, seriados da internet, partidas de futebol, games, a vida das celebridades, sucessos e fracassos da vida cotidiana e uma série de outras expressões. Logo, podemos dizer, são diversos elementos afetivos, jogos de projeção e identificação e emoções associadas ao dia a dia que circulam nas mensagens. Ou seja, é na integração de movimentos, cores, imagens e sons que as ideias e as representações que circulam pelos memes são dinamizadas. 


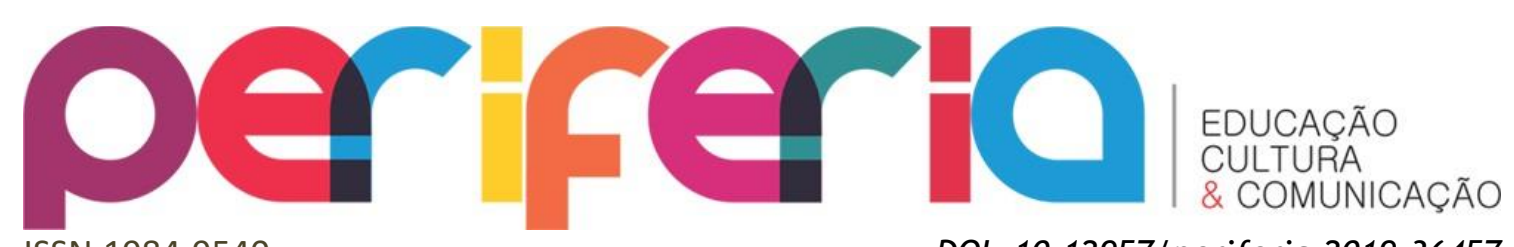

Como consequência, existe uma dimensão afetiva acionada pelos estudantes ao interagir com os memes.

Elementos capazes de mobilizar afetos perpassam todos os memes e, por isso, tratamos as categorias de análise a partir do conceito de dominância. Ou seja, cotidiano, afetos e zoeira mantém entre si relação de diálogo, tendo em um meme específico a prevalência de um elemento em relação ao outro. Na categoria de afetos, gostaríamos de enfatizar que os estudantes se valem dessa função de mobilizar afetos nos memes para se relacionar com os pares. Vejamos um exemplo, seguido de um depoimento do estudante, que demonstra como constamos essa perspectiva na investigação de campo: 


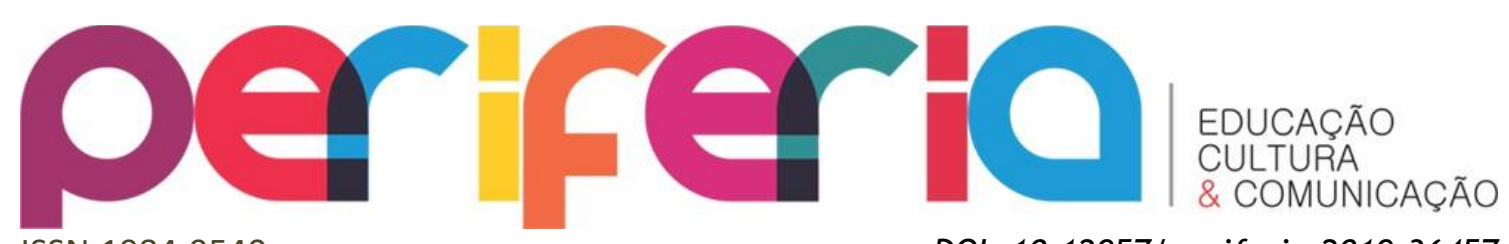

ISSN:1984-9540

DOI: $10.12957 /$ periferia.2019.36457

Imagem 2 - Meme selecionado durante a investigação de campo

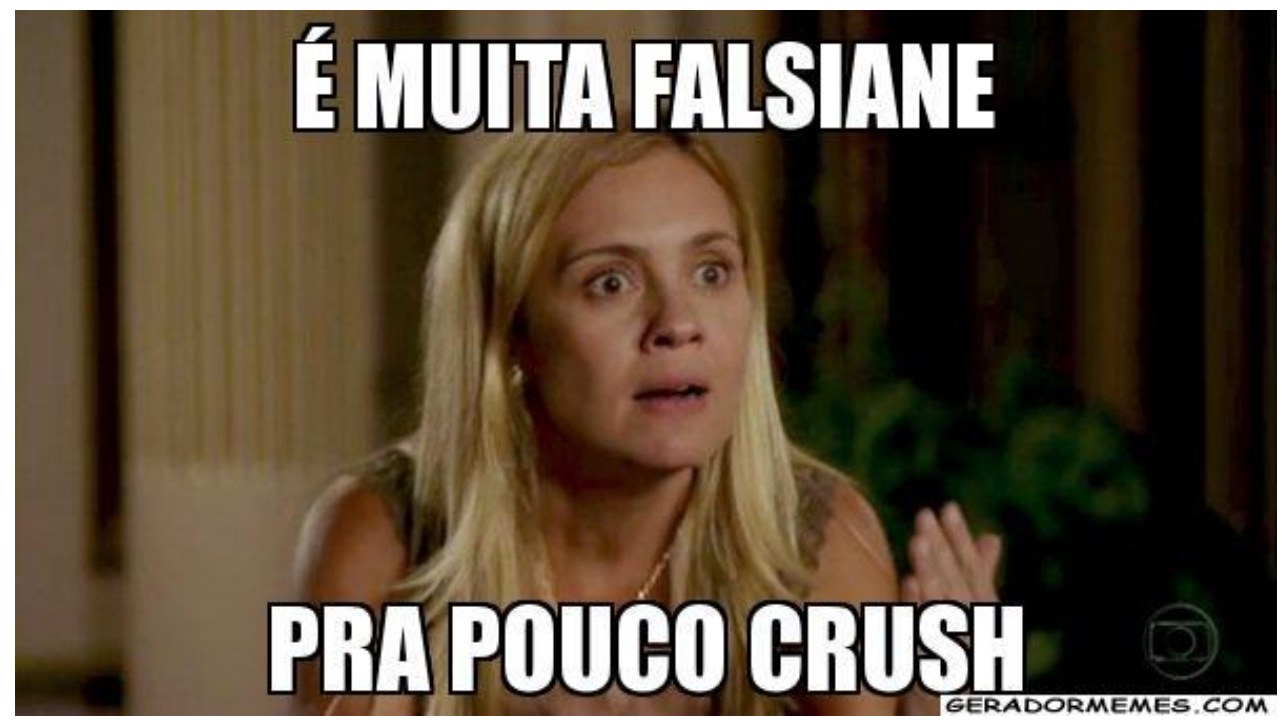

Fonte: Facebook (2016). Legenda: A imagem remete à personagem Carminha, interpretada por Adriana Esteves na novela da Rede Globo “Avenida Brasil”. Carminha é popular na linguagem dos memes e frequentemente utilizada para montagens na internet.

A vida tá assim agora, tem muitas falsianes, mas crush que é bom, nada. Depoimento 4

Podemos notar que a inter-relação do meme com o depoimento faz referência aos atritos, às emoções e às tensões que compõem o cotidiano dos jovens. Quando pensamos na alta intensidade de utilização das redes sociais pelos entrevistados, não é obra do acaso que as relações entre eles sejam dinamizadas pelas mensagens e provocações dos memes. Entre os 18 estudantes de nossa amostragem, 7 declararam usar as redes sociais a cada 10 minutos. Outros 8 pelo menos uma vez a cada hora. Logo, devemos levar em consideração que se relacionar nas redes sociais é uma constante. Como consequência, a dimensão afetiva, de interação com amigos e amigas, é feita de forma híbrida com a linguagem digital. Muitas vezes, mesmo que estejam próximos fisicamente, é nas redes sociais que eles se comunicam, trocam mensagens e vivenciam as experiências cotidianas, como, por exemplo, indiretas no 


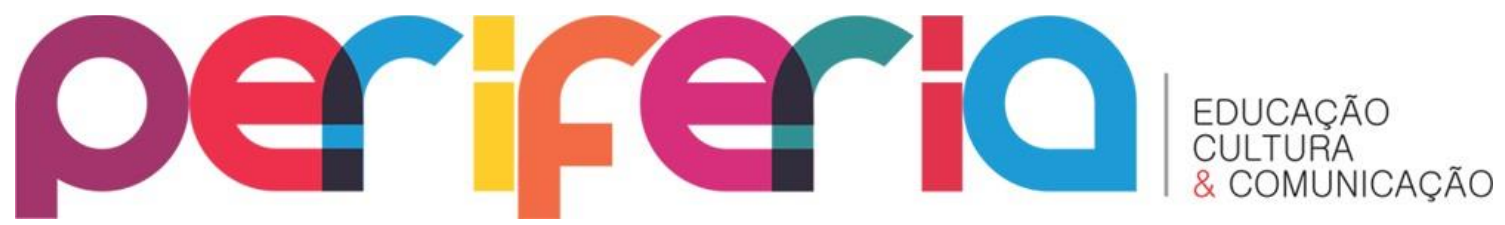

ISSN:1984-9540

DOI: $10.12957 /$ periferia.2019.36457

Facebook, ciúmes da melhor amiga, predominância de falsianes ${ }^{7}$ em detrimento dos crushes $^{8}$ e assim por diante.

\subsection{Memes da zoeira}

Podemos categorizar: os estudantes entrevistados reconhecem nos memes o principal produto daquilo que eles classificam como "zoeira". Vejamos um exemplo e depoimento que nos permitem compreender as representações que circundam o assunto.

Imagem 31 - Meme selecionado durante a investigação de campo

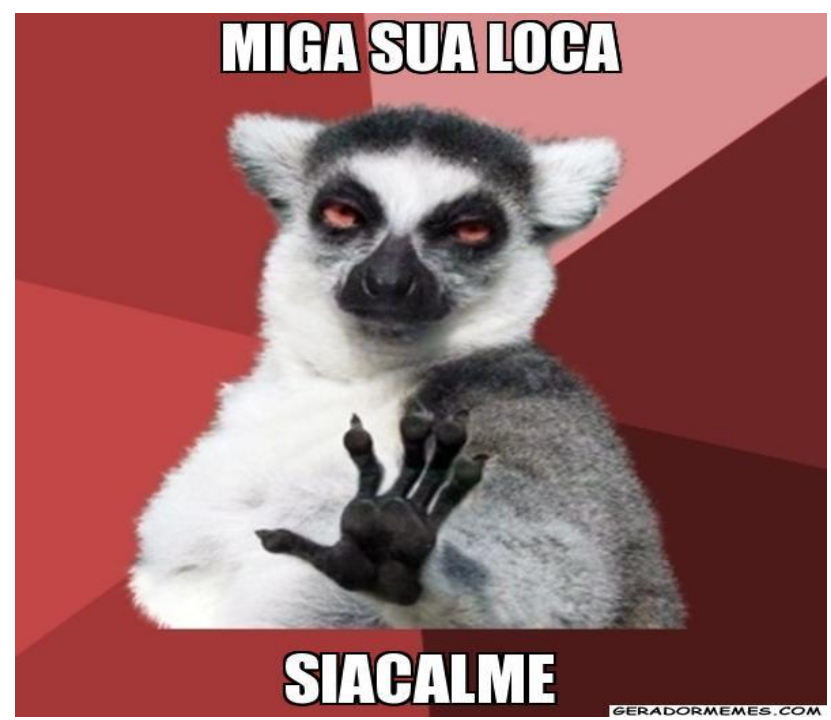

Fonte: Facebook (2016). Legenda: A expressão “miga, sua loca” é extremamente popular

\footnotetext{
${ }^{7}$ Extremamente popular nas redes sociais, o termo falsiane é empregado para se referir às pessoas que são falsas ou têm uma conduta duvidosa. Como demonstram os depoimentos dos entrevistados de nossa pesquisa, falsianes são geralmente identificados como pessoas que costumam "falar nas costas" e terem atitudes dúbias e, sobretudo, mentirosas. Assim como falsiane, escrotiane, otariane, obesiane e outros designativos terminados em "iane" fazem parte do vocabulário de criações livres das redes sociais.

${ }^{8}$ Nas redes sociais, crush é uma pessoa que se deseja paquerar ou que já se esteja paquerando. No caso da paquera se converter em encontro, beijo ou algo do gênero, não trata-se mais de crush, mas sim "date", na acepção semelhante à língua inglesa.
} 


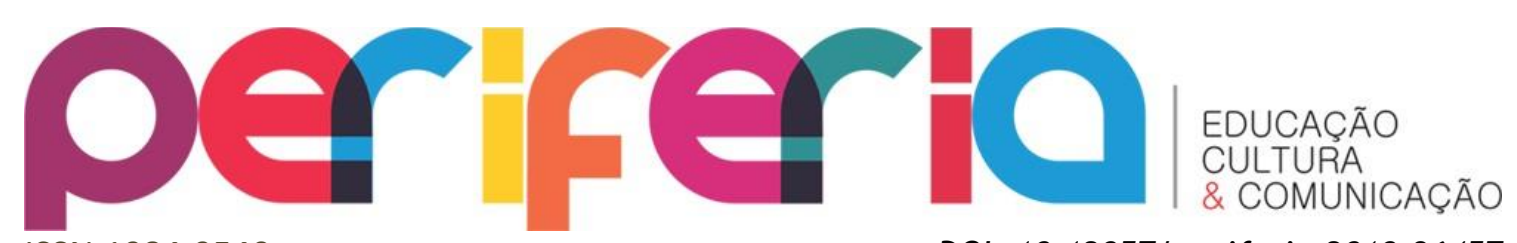

ISSN:1984-9540

DOI: $10.12957 /$ periferia.2019.36457

nas redes sociais. Na imagem, ao usar a expressão "siacalme", é possível notar uma prática comum na rede: criação de neologismos e criações livres.

Miga, sua loca, se acalme. Não precisa ficar estressada. É muito engraçado.

Depoimento 5.

Em termos de linguagem, Possenti (2014) explica que há diversas formas de acionar o humor. Repetições, exageros e, sobretudo, surpresas sequenciais, ou seja, fatos que desestabilizam um final esperado ou tenham capacidade de romper com a lógica, são típicos das narrativas cômicas. Para o autor de Humor, língua e discurso, é possível provocar o riso tanto pela técnica quanto pelo sentido, o que significa que, a depender da intenção, vários elementos podem desencadear os efeitos necessários para ativar o cômico. No entanto, é nas referências aos paradoxos e às controvérsias da vida que o humor geralmente acontece. Os temas que causam desconforto ou surpresa, sobretudo se "as controvérsias que se tornaram mais ou menos populares e algum dos aspectos relacionados ao tema foi estereotipado" (POSSENTI, 2014, p. 51), são fontes inesgotáveis de piada, pois podem produzir sentido a partir de polêmicas e tabus.

No mundo contemporâneo, a busca pelos prazeres imediatos, pela sedução e o divertimento é uma marca estrutural da navegação nas redes sociais. Em detrimento dos textões e de expressões narrativas que exigem maior elaboração, o humor emerge como potência de circulação nas redes: eles atendem rapidamente os anseios dos usuários da internet. A desobrigação com certos "esforços" intelectuais, como explica Possenti (2014), é elemento fundamental para o cômico. A velocidade de compartilhamentos e a própria configuração das redes.

Durante a investigação de campo era evidente a empolgação dos estudantes para "praticar a zoeira". Ao suscitar - no título do artigo - a expressão zoeira, chamamos atenção a uma das facetas dessa nova forma de se relacionar no mundo, onde o humor permite intervenções sobre o cotidiano, conforme a imagem acima demonstra. 


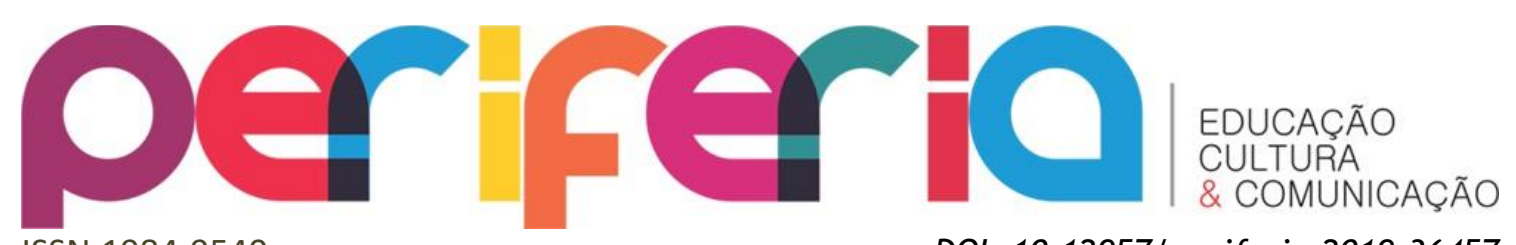

ISSN:1984-9540

DOI: 10.12957/periferia.2019.36457

\section{CONCLUSÃO}

A partir da investigação de campo e da análise sobre as categorias de cotidiano, afetos e zoeira, elaboramos a definição do gênero meme: em termos de tipologia textual, memes relatam situações, fatos e expressões a partir de montagens e jogos de linguagem construídos nas redes sociais. Com referências intertextuais e interdiscursivas aos produtos midiáticos que circulam no ciberespaço, os memes são narrativas que materializam - em micronarrativas - os enunciados formados por composições visuais-verbais, cuja finalidade é a interação com os pares. Nesse sentido, com personagens reais (como celebridades e atletas profissionais) ou imaginários (como animais de estimação que dialogam com humanos), os memes ocorrem de acordo com as cadeias comunicativas que os usuários da internet buscam ativar.

Apropriados em larga escala, os memes sintetizam o momento histórico-social em que a comunicação passou a ocupar papel decisivo em termos de produção, circulação e recepção dos bens simbólicos. Nesse aspecto, há uma nova dimensão da ação comunicativa - organizada em redes rizomáticas -, que impõe desafios a diversos setores da sociedade. A presente dissertação se concentrou em um locus específico: o universo da escola, a partir do olhar de estudantes do ensino fundamental.

Com essas definições, a pesquisa de mestrado aponta o complexo território de transformações que marcam o cotidiano juvenil. Nos entrelaçamentos entre Educomunicação e a "zoeira", demonstramos como novas modalidades de comunicação fazem parte da rotina dos discentes, forjando sociabilidades e os modos de compreensão da realidade. Foi possível deduzir que há nos memes funções que se articulam com o intuito de narrar e representar o cotidiano, assim como dinamizar jogos de paquera, amizades e inimizades entre outras possibilidades. Verificamos também que a zoeira é um dos elementos centrais nas brincadeiras no interior da escola. 


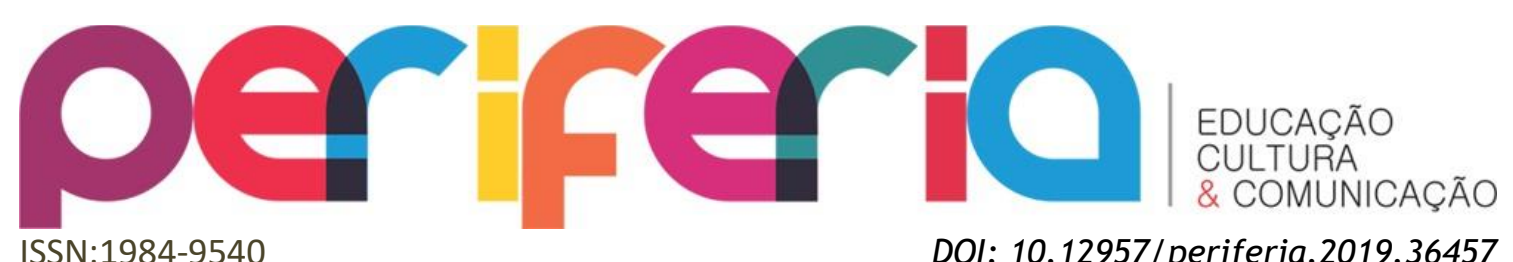

Compreender como funciona um meme, em última instância, constitui um passo significativo para construir pontes e interlocuções com os discentes. Há nos dias atuais, como apresentamos no decorrer da pesquisa, novos códigos e formas de organização da linguagem, que evidencia como alunos e alunas constroem expressões comunicativas sob sigla diferente das "tradicionais". "Miga, sua loka", "como você é burro, cara”, “crush”, "falsiane” e tantos outros exemplos mostram que há, de fato, uma nova maneira de se relacionar com o mundo pouco compreendida pelo universo adulto. Sem pretensões generalizantes, acredito que a pesquisa de mestrado, mesmo que modestamente, conseguiu respostas sobre esse universo tão pouco compreendido enquanto fenômeno comunicacional.

\section{REFERÊNCIAS}

BACCEGA, Maria. Comunicação/educação e a construção de nova variável histórica. In: Educomunicação: construindo uma nova área do conhecimento. CITELLI, Adilson ; Costa, Maria. (org.). São Paulo: Paulinas, 2011.

BLACKMORE, Susan. Susan Blackmore sobre memes e "temes". TEDTalks, publicado em fev. de 2008. Disponível em:

<https://www.ted.com/talks/susan_blackmore_on_memes_and_temes?language=p t-br>. Acesso em 15 de dez. de 2016.

CALIXTO, D. Memes na internet: entrelaçamento entre Educomunicação, cibercultura e a 'zoeira' de estudantes nas redes sociais. São Paulo: USP, 2017, 220 f. Dissertação (Mestrado em Ciências da Comunicação) - Programa de Pós-

Graduação em Ciências da Comunicação, área de concentração: Interfaces Sociais. Linha de Pesquisa: Comunicação e Educação, USP, São Paulo, 2017..

CITELLI, Adilson. O texto argumentativo. São Paulo: Scipione, 1994.

CITELLI, Adilson. Comunicação e Educação: a linguagem em movimento. $3^{\text {a }}$ edição, São Paulo: Senac São Paulo, 2004.

CITELLI, Adilson. Comunicação e educação: implicações contemporâneas. In:

Educomunicação: construindo uma nova área do conhecimento. CITELLI, A. ; Costa, M. (org.). São Paulo: Paulinas, 2011.

COMITÊ GESTOR DA INTERNET NO BRASIL. Pesquisa TIC KIDS ONLINE 2016. São Paulo: GCl.br, 2016. Disponível em: < http: //cetic.br/pesquisa/kids-online/> Acesso em 19 de dezembro de 2016. 


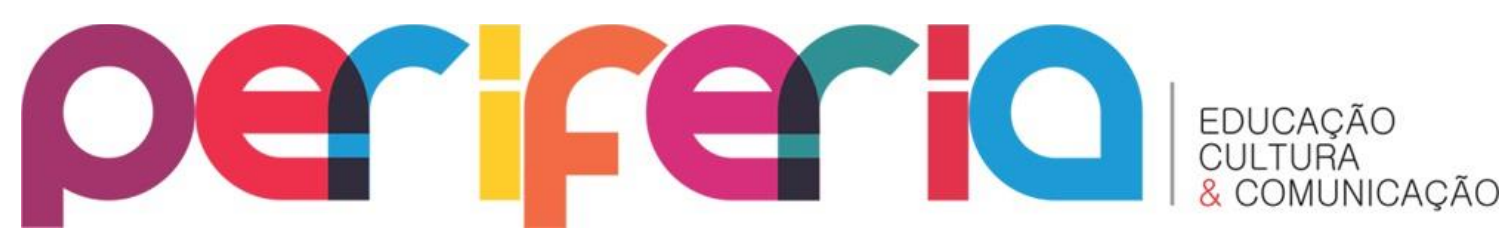

DANTAS, Marcos. A lógica do capital-informação: a fragmentação dos monopólios e a monopolização dos fragmentos num mundo de comunicações globais. $2^{a}$ edição. Rio de Janeiro: Contraponto, 2002.

DAWKINS, Richard. O gene egoísta. Le Livros, PDF Online, 1976. Disponível em: <https://goo.gl/PrJrb9>. Acesso em 10 fev. 2016.

KÖCHE, Vanilda ; MARINELLO, Adiane. Gêneros textuais: práticas de leitura escrita e análise linguística. Petrópolis: Vozes, 2015.

LEMOS, André. Cibercultura: tecnologia e vida social na cultura contemporânea. $7^{\text {a }}$ edição. Porto Alegre: Sulina, 2015.

LOPES, Maria. Pesquisa em Comunicação. São Paulo, Edições Loyola: São Paulo, 2005.

LULKIN, Sérgio Andrés. O riso nas brechas do siso. Porto Alegre: UFRGS, 2007, 184 f. Tese (Doutorado em Educação) - Programa de Pós-Graduação em Educação, UFRGS, Porto Alegre, 2007.

MARCUSCHI, L. A. Gêneros Textuais: Definição e Funcionalidade. In: Gêneros Textuais: Constituição e Práticas. Cortez Online, 2009. Disponível em: <https://goo.gl/UsxD85>. Acesso em 10 de jul. de 2017.

MARTÍN-BARBERO, Jesús. Dos meios às mediações: comunicação, cultura e hegemonia. Rio de Janeiro: Editora UFRJ, 1997.

POSSENTI, Sírio. Humor, língua e discurso. São Paulo: Contexto, 2014.

RECUERO, Raquel. Redes Sociais na Internet. $2^{\mathrm{a}}$ edição, Porto Alegre: Sulina, 2014.

SHIFMAN, L. Memes in Digital Culture. Londres, Inglaterra: The MIT PRESS, 2014.

SHIRKY, C. Lá vem todo mundo: o poder de organizar sem organizações. Rio de Janeiro: Zahar, 2012. 